\title{
ANTIOXIDANT ACTIVITY TEST OF FRACTIONS FROM STAR FRUIT LEAVES (AVERRHOA CARAMBOLA L.) FROM THREE REGIONS IN WEST JAVA
}

\author{
ANNISA DHANIRA, BERNA ELYA*, KATRIN BASAH \\ Faculty of Pharmacy, Universitas Indonesia, Depok, 16424 West Java, Indonesia. Email: berna.elya@farmasi.ui.ac.id
}

Received: 30 September 2019, Revised and Accepted: 23 December 2019

\begin{abstract}
Objectives: Previous in vitro research showed that ethyl acetate fractions of star fruit leaves exhibit strong antioxidant activities toward 2,2-diphenyl1-picrylhydrazyl (DPPH) radical ( $\mathrm{IC}_{50}=90 \mu \mathrm{g} / \mathrm{ml}$ ). This study's aim was to evaluate antioxidant activity of fractions from leaf extracts from star fruit sourced from three different regions in Indonesia (Depok, Sukabumi, and Subang) and, for the most active fraction (that with the highest antioxidant activity), determine whether there was any correlation with phenolic and flavonoid content.
\end{abstract}

Methods: Liquid-liquid partitioning, fractions were evaluated for in vitro antioxidant activity using DPPH radical scavenging and ferric reducing ability of plasma (FRAP) assay.

Results: The ethyl acetate fraction from the Subang region exhibited the strongest radical scavenging activity with both the $\mathrm{DPPH}$ assay $\left(\mathrm{IC}_{50}=96 \mu \mathrm{g} / \mathrm{ml}\right)$ and the FRAP assay (FeEAC value $=1405 \mu \mathrm{mol} / \mathrm{g}$ ).

Conclusion: Ethyl acetate fractions from star fruit leaves could be used as natural antioxidants. No correlation was found between antioxidant activity and phenolic or flavonoid content.

Keywords: Antioxidant, 2,2-diphenyl-1-picrylhydrazyl, Fractionation, Ferric reducing ability of plasma, Star fruit.

(C) 2020 The Authors. Published by Innovare Academic Sciences Pvt Ltd. This is an open access article under the CC BY license (http://creativecommons. org/licenses/by/4. 0/) DOI: http://dx.doi.org/10.22159/ijap.2020.v12s1.FF019

\section{INTRODUCTION}

Star fruit is distributed around the world, especially in tropical countries such as India, Malaysia, Indonesia, and Philippines. Star fruit belongs to the genus Averrhoa, containing five species; Averrhoa bilimbi, Averrhoa carambola, Averrhoa dolichocarpa, Averrhoa leucopetala, and Averrhoa microphylla. A. carambola is the species most widely produced on a commercial scale and is, therefore, considered the most important. It is cultivated in the Asia Pacific region on a large scale and is also popular in the American and Australian markets [1]. Previous research demonstrated that ethyl acetate and n-butanol fractions of $A$. carambola ethanolic extract have high antioxidant activity, as measured by the 2,2-diphenyl-1-picrylhydrazyl (DPPH) and iron (Fe) reduction methods [2].

Among the chemical compounds present in A. carambola are apigenin, quercetin, anisaldehyde, gallic acid, cyanidin, epigallocatechin, beta-sitosterol, beta-amyrin, proanthocyanidin, lupeol, rutin, and Vitamin C [3]. Results from quantitative analyses have shown that star fruit leaves fulfill Farmakope Herbal Indonesia requirements with respect to flavonoid levels; they contain apigenin (6.37\%) and quercetin (4.49\%) in the ethyl acetate fraction [4]. This study's aims were to determine antioxidant activity in leaf fractions from $A$. carambola from three different regions in West Java (Depok, Sukabumi, and Subang), to determine total phenolic and flavonoid content in relation to antioxidant activity and to detect any regional differences. West Java was chosen as the sampling site since it is a tropical area with high rainfall (2000-4000 mm per annum) and varied geography, with mountainous areas in the central and southern parts and lower-lying areas in the northern part [5].

The ferric reducing ability of plasma (FRAP) antioxidant capacity assay was used to reduce a ferric tripyridyltriazine (TPTZ) complex to the ferrous form, resulting in an intense blue color whose absorbance can be measured at $593 \mathrm{~nm}[6]$. While the FRAP method is based on a single electron transfer mechanism, the principle underlying the DPPH method is delocalization of free electrons, giving rise to a violet color whose absorbance is measured at $515 \mathrm{~nm}$. The reaction between DPPH and a hydrogen donor reduces the violet color intensity due to the reduction of DPPH to DPPH-H [7].

\section{METHODS}

The research was carried out in the Phytochemistry and Pharmacognosy Laboratory at Universitas Indonesia, Depok, from January 2018 to May 2018. Dried A. carambola leaves from three different regions (Depok, Sukabumi, and Subang) were used. Extraction was done by maceration in $70 \%$ ethanol, with a sample: solvent ratio of 1:10 (w/v). Fractionation was performed by liquid-liquid partitioning using three solvents of different polarity; ethyl acetate, hexane, and distilled water. A water bath and rotary vacuum evaporator were used to obtain the viscous extract for the subsequent assay [8].

Preliminary DPPH antioxidant activity tests were performed on all fractions (ethyl acetate, hexane, and water) in a round-bottomed microplate with a 1:1 ratio of DPPH and sample $(100 \mu \mathrm{L}$ DPPH solution [200 $\mu \mathrm{g} / \mathrm{ml}]$ and $100 \mu \mathrm{L}$ sample solution). The plate was incubated in the dark for $30 \mathrm{~min}$ at room temperature. The absorbance was read at $515 \mathrm{~nm}$ [9]. In this DPPH test, sample concentrations need to be the same to determine the most active fraction; in this study, the sample concentration for all fractions tested was $1000 \mu \mathrm{g} / \mathrm{ml}$. Then, the most active fraction from preliminary testing was further tested to obtain its half-maximal inhibitory concentration $\left(\mathrm{IC}_{50}\right)$. The scavenging capacity (\%) was calculated with the formula:

$$
\frac{\mathrm{A}_{\text {control }}-\mathrm{A}_{\text {sample }}}{\mathrm{A}_{\text {control }}} \times 100
$$


where $\mathrm{A}_{\text {control }}$ is the absorbance of methanol and DPPH solution, and $\mathrm{A}_{\text {sample }}$ is the absorbance of sample and DPPH solution [10].

The FRAP antioxidant activity assay was carried out as previously described. The FRAP working solution was a mixture of acetate buffer ( $300 \mathrm{mM}, \mathrm{pH} 3.6)$, TPTZ (10 mM dissolved in HCL $40 \mathrm{mM})$, and $\mathrm{FeCl}_{3}(20 \mathrm{mM}$ dissolved in distilled water). Using a micropipette, $20 \mu \mathrm{L}$ of either the sample or ferrous ammonium sulfate (AFS; a standard solution for producing a standard curve) and $280 \mu \mathrm{L}$ of FRAP working solution were added to the microplate wells. The mixture was shaken and incubated for $30 \mathrm{~min}$ at $37^{\circ} \mathrm{C}$ before its absorbance at $593 \mathrm{~nm}$ was recorded. All assays were done in triplicate [11].

Total phenolic content was measured by ultraviolet (UV)-visible spectrophotometry based on Farmakope Herbal Indonesia methods with gallic acid as a standard. Five milliliters Folin-Ciocalteu reagent (7.5\% in distilled water) was added to each $1-\mathrm{ml}$ tube of sample or diluted standard solution. The mixture was incubated for $8 \mathrm{~min}$ before $4 \mathrm{ml}$ of $1 \% \mathrm{NaOH}$ was added. Then, the mixture was further incubated for $1 \mathrm{~h}$ before its absorbance was read at $730 \mathrm{~nm}$ [12].

The total flavonoid content was measured by UV-visible spectrophotometry with rutin as standard. The sample contained $5 \mathrm{ml}$ of extract solution dissolved in methanol and $5 \mathrm{ml}$ of $2 \% \mathrm{AlCl}_{3}(\mathrm{~b} / \mathrm{v}$ in methanol). The sample was incubated for $10 \mathrm{~min}$. Methanolic $2 \% \mathrm{AlCl}_{3}$ was used as a blank. Absorbance was read at $430 \mathrm{~nm}$ [13].

Before the detailed quantitative analyses, we carried out preliminary qualitative tests using thin-layer chromatography (TLC) and DPPH spray reagent; increasing intensity of yellow coloration developing on the plate indicated increasing antioxidant concentration.

Flavonoid identification was done using TLC with chloroform:acetone:formic acid (10:2:1) as the mobile phase and 5\% $\mathrm{AlCl}_{3}$ spray reagent, with quercetin as the positive control.

\section{RESULTS AND DISCUSSION}

Qualitative analysis results showed that the ethyl acetate fraction of A. carambola leaves exhibited the greatest concentration of antioxidants, while the concentration in the hexane fraction was low. A possible explanation could be that star fruit contains polyphenolic compounds as the major component which is still extracted by less polar solvents. Preliminary DPPH quantitative testing was done using quercetin as positive control (Fig. 1). Preliminary DPPH quantitative antioxidant testing highlighted the ethyl acetate fraction of A. carambola leaves from Subang as the most active (Fig. 2), for which the $\mathrm{IC}_{50}$ value was $96 \mu \mathrm{g} / \mathrm{ml}$ (Fig. 3 and Table 1). It could be that environmental (e.g., geography and climate) parameters were optimum for A. carambola in Subang. Chemical compounds that may have a role in antioxidant activity are polyphenols (flavonoids, tannins, etc.). A previous study showed that antioxidant activity in the ethyl acetate fraction of $A$. carambola leaves was significantly correlated with total phenolic content $\left(r^{2}=0.997\right)$, though such a relationship was not evident in this study. It will be discussed further in the next section.

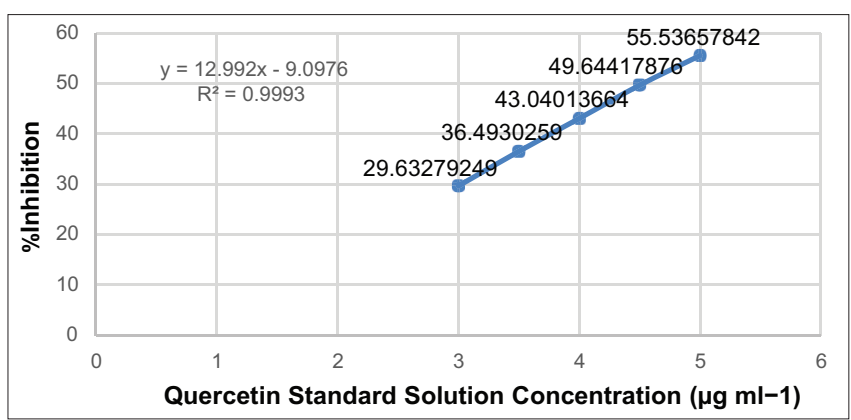

Fig. 1: IC $_{50}$ plot for quercetin as a positive control
TLC analysis for flavonoids showed that the ethyl acetate fraction of A. carambola leaves contained flavonoids, as indicated by yellowish fluorescent bands in the UV-visible spectrograph at $366 \mathrm{~nm}$ (Fig. 4). The bands occurred not only in same the retention zone as quercetin but also elsewhere as well, indicating the presence of flavonoids other than quercetin (Fig. 4, left panel). Using the same mobile phase, the antioxidant content was analyzed, with gallic acid as the positive control and DPPH solution at $100 \mu \mathrm{g} / \mathrm{ml}$ as the spray reagent. The lower, higher polarity area of the TLC plate indicated good antioxidant activity (the yellow spot on the violet background; Fig. 4, right panel).

The FRAP antioxidant assay results showed that the ethyl acetate fraction of $A$. carambola leaves from the Subang region gave the highest value $(1405 \mu \mathrm{mol} / \mathrm{g})$. The complete data are shown in Fig. 5 and Table 2. This was lower than for the standard (gallic acid) which, at a concentration of $25 \mathrm{ppm}$, gave a value of $26,863 \mu \mathrm{mol} / \mathrm{g}$. These results reflected the purity of the standard versus the variety of compounds in the sample. Gallic acid was used as the standard to allow comparison with the determination of total phenolic content using the Folin-Ciocalteu method (both this method and the FRAP method are classified as indirect methods of antioxidant assay not involving chemical radicals). Ferrous ammonium sulfate standard was

Table 1: $\mathrm{IC}_{50}$ data for ethyl acetate fraction of Averrhoa carambola leaves from Subang, the most active fraction

\begin{tabular}{ll}
\hline Concentration & \% Inhibition \\
\hline 50 & 29.62 \\
75 & 39.29 \\
100 & 51.39 \\
125 & 66.21 \\
150 & 72.29 \\
\hline
\end{tabular}

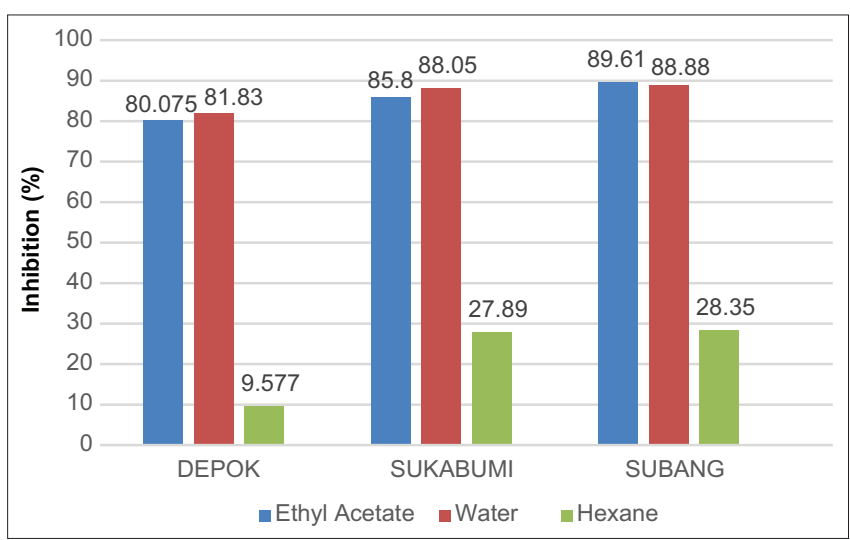

Fig. 2: Antioxidant levels for leaf fractions of Averrhoa carambola from three regions in West Java as shown by preliminary DPPH testing

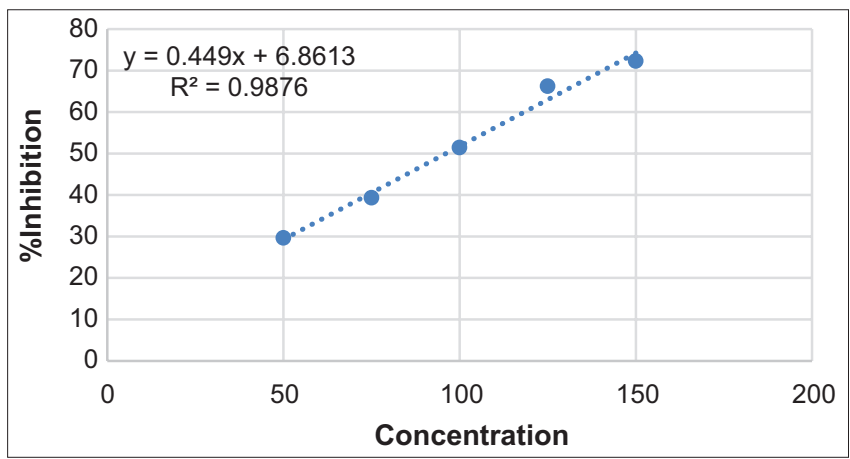

Fig. 3: $\mathrm{IC}_{50}$ curve for ethyl acetate fraction of Averrhoa carambola leaves from Subang, the most active fraction 
Table 2: FeEAC values in Averrhoa carambola leaf fractions from three regions in West Java (Depok, Sukabumi, and Subang)

\begin{tabular}{ll}
\hline Sample & FeEAC $(\boldsymbol{\mu m o l} / \mathbf{g})$ \\
\hline Ethyl acetate fraction from Depok & 1203 \\
Ethyl acetate fraction from Sukabumi & 1277 \\
Ethyl acetate fraction from Subang & 1405 \\
Water fraction from Depok & 793 \\
Water fraction from Sukabumi & 886 \\
Water fraction from Subang & 1022 \\
Hexane fraction from Depok & 670 \\
Hexane fraction from Sukabumi & 701 \\
Hexane fraction from Subang & 936 \\
\hline
\end{tabular}
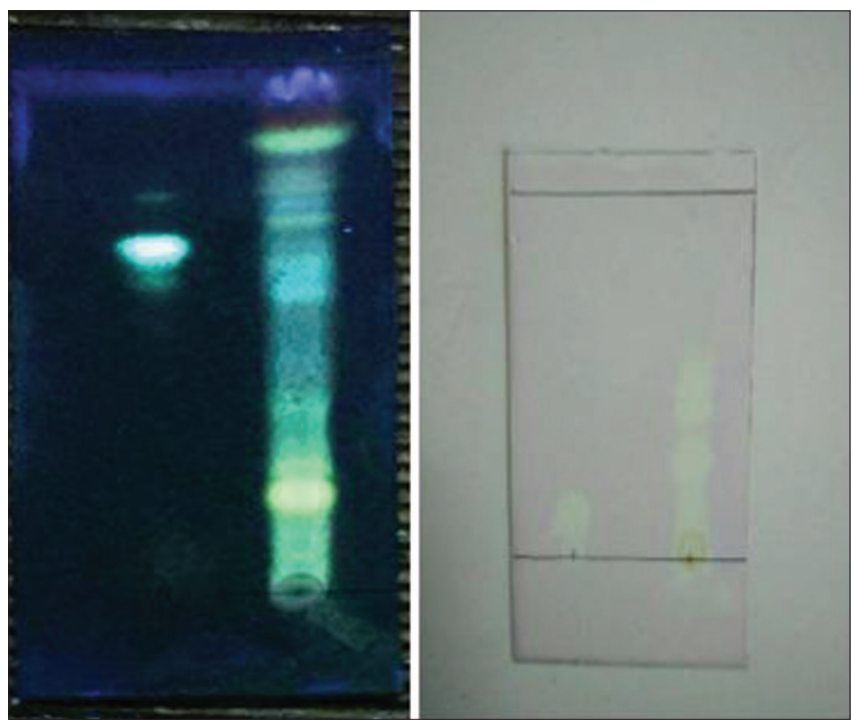

Fig. 4: Flavonoid identification and antioxidant spot sprayed by DPPH on ethyl acetate fraction of Averrhoa carambola leaves from Subang, the most active fraction

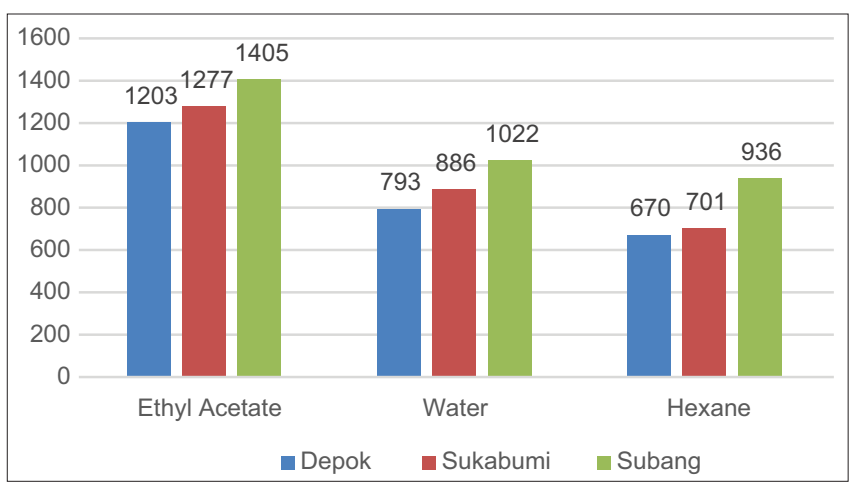

Fig. 5: FeEAC values for leaf fractions of Averrhoa carambola from three regions in West Java (Depok, Sukabumi, and Subang)

used as a calibration curve. The absorbance data are shown in Table 3 and Fig. 6.

In this study, the total phenolic and flavonoid content in A. carambola leaves was determined using the most active fraction, obtained using ethyl acetate, with phenolic content expressed as gallic acid equivalent and flavonoid content expressed as rutin equivalent. The gallic acid calibration curve is shown in Table 4 and Fig. 7. The rutin calibration curve is shown in Fig. 8 and Table 5. Phenolic contents for leaf fractions of A. carambola from three regions in West Java (Depok, Sukabumi, and Subang) are shown in Table 6. Flavonoid concentrations for leaf fractions of A. carambola from three regions in West Java (Depok,
Table 3: Absorbance data for the ferrous ammonium sulfate standard

\begin{tabular}{ll}
\hline Concentration $(\boldsymbol{\mu M})$ & Absorbance \\
\hline 26.67 & 0.204 \\
33.33 & 0.316 \\
40 & 0.393 \\
46.67 & 0.521 \\
53.33 & 0.611 \\
60 & 0.717 \\
\hline
\end{tabular}

Table 4: Gallic acid calibration curve

\begin{tabular}{ll}
\hline Concentration $(\boldsymbol{\mu g} / \mathrm{ml})$ & Absorbance \\
\hline 1 & 0.242 \\
1.5 & 0.351 \\
2 & 0.436 \\
2.5 & 0.539 \\
3 & 0.632 \\
3.5 & 0.752 \\
\hline
\end{tabular}

Table 5: Rutin calibration curve

\begin{tabular}{ll}
\hline Concentration & Absorbance \\
\hline 10 & 0.28 \\
12.5 & 0.387 \\
15 & 0.473 \\
17.5 & 0.575 \\
20 & 0.662 \\
22.5 & 0.747 \\
\hline
\end{tabular}

Table 6: Total phenolic content of ethyl acetate fraction of Averrhoa carambola leaves from three locations

\begin{tabular}{ll}
\hline Sample & $\begin{array}{l}\text { Phenolic content } \\
\text { (mg GAE/g) }\end{array}$ \\
\hline Ethyl acetate fraction from Sukabumi & 76.7 \\
Ethyl acetate fraction from Subang & 61.3 \\
Ethyl acetate fraction from Depok & 56.3 \\
\hline mg GAE/g: mg gallic acid equivalent per g &
\end{tabular}

Table 7: Total flavonoid content of the ethyl acetate fraction of Averrhoa carambola leaves from different locations

\begin{tabular}{ll}
\hline Sample & $\begin{array}{l}\text { Flavonoid content } \\
\text { ( } \mu \text { g rutin equivalent/g sample) }\end{array}$ \\
\hline $\begin{array}{l}\text { Ethyl acetate fraction from } \\
\text { Sukabumi }\end{array}$ & 2609 \\
Ethyl acetate fraction from Subang & 2491 \\
Ethyl acetate fraction from Depok & 673 \\
\hline
\end{tabular}

Sukabumi, and Subang) are shown in Table 7. Levels of both were highest in leaves from the Sukabumi region followed by Subang and Depok.

One disadvantage of the antioxidant assay with the DPPH method is steric stability. Low molecular weight molecules have a greater chance of reacting with radicals, causing high total antioxidant capacity readings [14]. Another disadvantage is that radicals can react with reductants that do not possess antioxidant activity. For example, DPPH can be reduced to DPPH-H by $\mathrm{H}_{2} \mathrm{O}_{2}$ which is obviously not an antioxidant. In polar protic solvents (such as ethanol and methanol: DPPH can be dissolved in water), the reaction between DPPH and phenolic compounds can be accelerated by stepwise proton-transfer electron-transfer mechanism [15]. 


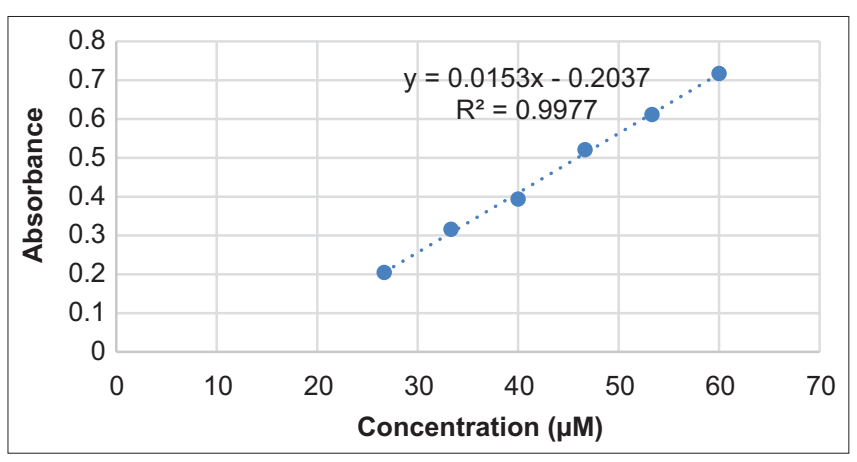

Fig. 6: Calibration curve for the FAS standard

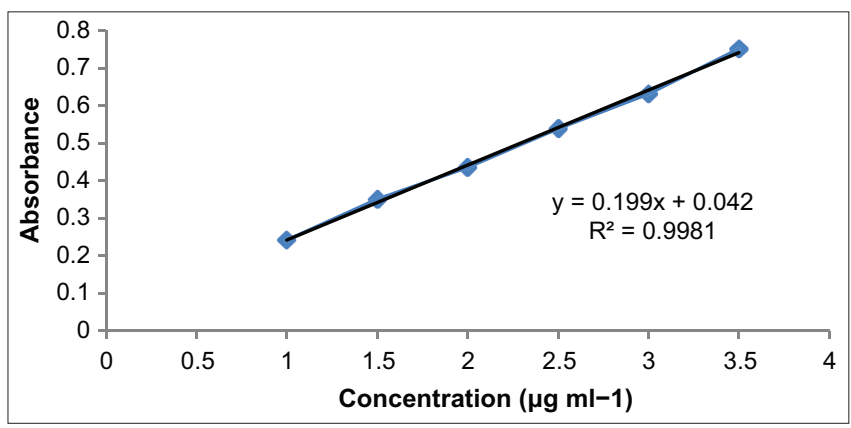

Fig. 7: Gallic acid calibration curve

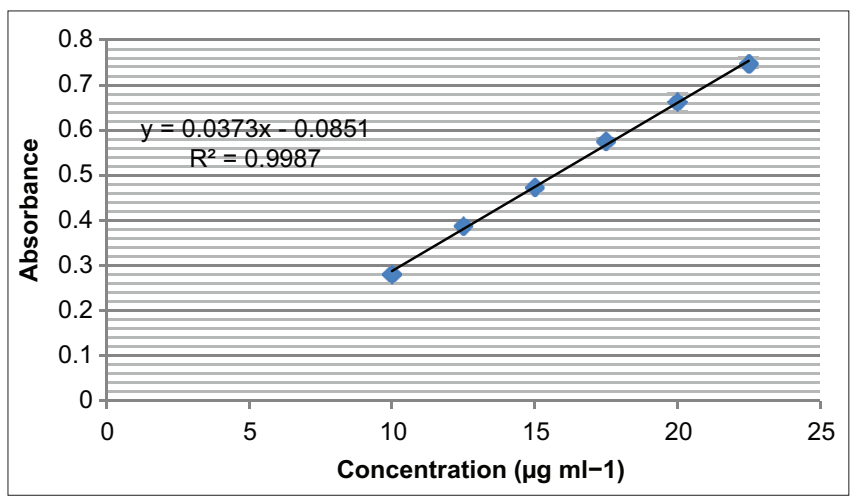

Fig. 8: Rutin calibration curve

A disadvantage of antioxidant assay with the FRAP method is that values can vary depending on the analysis time-scale. Fast-reacting phenols that can bond with Fe or break into less reactive components may be analyzed satisfactorily with a short incubation time. In one study involving a FRAP assay on dietary polyphenols in water and methanol, absorbance increased slowly for caffeic acid, tannic acid, ferulic acid, ascorbic acid, and quercetin although the incubation period was over some hours. This shows that absorption at a single time point may not represent a complete reaction [16].

\section{CONCLUSION}

Based on DPPH and FRAP assays of 70\% ethanolic extracts, the highest antioxidant activity detected in ethyl acetate fractions was from A. carambola leaves from the Subang region $\left(\mathrm{IC}_{50}=96.077 \mu \mathrm{g} / \mathrm{ml}\right.$, with FeEAC value of $1405 \mu \mathrm{mol} / \mathrm{g}$ ). In this fraction, the total phenolic content was $61.32 \mathrm{mg}$ gallic acid equivalent/g and total flavonoid content was $2491 \mu \mathrm{g}$ rutin equivalent/g. There was no correlation between antioxidant activity and total phenolic or flavonoid content from the ethyl acetate fraction across three different regions (Depok, Sukabumi, and Subang). These results indicate that ethyl acetate leaf fractions of $A$. carambola would be valuable for antioxidant activity; however, further assay testing is required to find the correlation between antioxidant activity and total phenolic or flavonoid content.

\section{ACKNOWLEDGMENTS}

The authors are thankful to Universitas Indonesia that had given financial support for this research.

\section{CONFLICTS OF INTEREST}

The authors report that they have no conflicts of interest.

\section{REFERENCES}

1. Muthu N, Lee SY, Phua KK, Bhore SJ. Nutritional, medicinal and toxicological attributes of star-fruits (Averrhoa carambola L.): A review. Bioinformation 2016;12:420-4

2. Moresco HH, Queiroz GS, Pizzolatti MG, Brighente I. Chemical constituents and evaluation of the toxic and antioxidant activities of Averrhoa carambola leaves. Braz J Pharmacogn 2012;22:319-24.

3. Saghir SA, Sadikun A, Kooi-Yeong KH, Murugaiyah V. Starfruit (Averrhoa carambola): From traditional uses to pharmacological activities. Bol latinoam Caribe Plantas Med Aromat 2013;12:209-19.

4. Yunarto N, Sulistyaningrum N. Quantitative analysis of bioactive compounds in extract and fraction of starfruit (Averrhoa carambola) leaves using high perfomance liquid chromatography. J Kefarmasian Indones 2017;7:26-33.

5. Pemerintah Provinsi Jawa Barat. Kondisi Geografis. Available from: http://www.jabarprov.go.id. [Last accessed on 2018 Feb 04].

6. Benzie IF, Strain JJ. Ferric reducing/antioxidant power assay: Direct measure of total antioxidant activity of biological fluids and modified version for simultaneous measurement of total antioxidant power and ascorbic acid concentration. Methods Enzymol 1999;299:15-27.

7. Pisochi AM, Negulescu GP. Methods for total antioxidant activity determination: A review. Biochem Anal Biochem 2011;1:106.

8. Elya B, Djajadisasta J, Nabilah. Lipoxygenase inhibitory assay of Averrhoa carambola L leaves extract. Int J ChemTech Res 2017;10:342-3.

9. Rajauria G, Jaiswal AK, Abu-Ghannam N, Gupta S. Effect of hydrothermal processing on colour, antioxidant and free radical scavenging capacities of edible Irish brown seaweeds. Intl J Food Sci Tech 2010;45:2485-93

10. Picking D, Chambers B, Barker J, Shah I, Porter R, Naughton DP, et al. Inhibition of cytochrome P450 activities by extracts of Hyptis verticillata Jacq.: Assessment for potential HERB-drug interactions. Molecules 2018;23:430.

11. Wong CW, Cheung WS, Lau YY, de la Torre AA, Owusu-Apenten R. A frap assay at $\mathrm{pH} 7$ unveils extra antioxidant activity from green, black, white, and rooibos tea but not apple tea. Food Nutr Rep 2015;1:16-23.

12. Ministry of Health Republic of Indonesia. Department of Health. Supplement II of Indonesian Herbal Pharmacopoeia. Jakarta: Ministry of Health Republic of Indonesia; 2011.

13. Khan AA, Gani A, Ahmad M, Masoodi FA, Amin F, Kousar S. Mushroom varieties found in the Himalayan regions of India: Antioxidant, antimicrobial, and antiproliferative activities. Food Sci Biotechnol 2016;25:1095-100.

14. Apak R, Gorinstein S, Böhm V, Schaich KM, Özyürek M, Güçlü K. Methods of measurement and evaluation of natural antioxidant capacity/ activity (IUPAC technical report). Pure Appl Chem 2013;85:957-98

15. Amorati R, Valgimigli L. Advantages and limitations of common testing methods for antioxidants. Free Radic Res 2015;49:633-49.

16. Prior RL, Wu X, Schaich K. Standardized methods for the determination of antioxidant capacity and phenolics in foods and dietary supplements. J Agric Food Chem 2005;53:4290-302. 